Państwo-Prawo-Administracja

$2(1) / 2016$

ISSN 2451-1676

DOI: http://dx.doi.org/10.21784/PPA.2016.008

DANIEL JUREWICZ

Regionalna Izba Obrachunkowa w Bydgoszczy

\title{
Czas popełnienia naruszenia dyscypliny finansów publicznych w kontekście przedawnienia karalności (wybrane aspekty)
}

\section{Temporal aspects of infringing public finance discipline in the context of statute of limitation (selected aspects)}

\section{Streszczenie:}

Obowiązująca ustawa o odpowiedzialności za naruszenie dyscypliny finansów publicznych ma na celu eliminację niepożądanych wzorców zachowań poprzez możliwość orzeczenia sankcji wobec sprawcy czynu, jak również realizację funkcji prewencyjnej. O tym, czy cele te są możliwe do zrealizowania, decydują między innymi szczegółowe rozwiązania zawarte $\mathrm{w}$ ustawie. Celem niniejszego opracowania jest wskazanie potrzeby poszerzonej debaty, zarówno na płaszczyźnie teoretycznej, jak i praktycznej, w zakresie skuteczności obowiązujących przepisów ustawy na przykładzie czasu popełnienia naruszenia dyscypliny finansów publicznych. 


\begin{abstract}
:
The current law on liability for breach of discipline in public finances is to eliminate undesirable behavior patterns through the possibility of a judgment sanctions against the perpetrator, as well as the implementation of the preventive function. Whether these goals are feasible is determined among other things, by detailed solutions contained in the Act. The aim of this study is to advocate the need for an enlarged debate, at both theoretical and practical levels, in terms of the effectiveness of the provisions of the Act on the example of the time when public finance discipline is infringed.
\end{abstract}

Słowa kluczowe: dyscyplina finansów publicznych; czas popełnienia czynu; przedawnienie karalności.

Keywords: discipline of public finance; the time the offense was committed; statute of limitation of criminal.

\title{
1. Wstęp
}

Gospodarowanie środkami publicznymi wymaga uwzględnienia zagadnień tzw. dóbr wspólnej puli. Zapewnienie racjonalnego gospodarowania tymi środkami wymaga zdefiniowania zasad gospodarowania oraz określenia sankcji za ich nieprzestrzeganie ${ }^{1}$. W polskim systemie funkcje te pełni ustawa z dnia 17 grudnia 2004 r. o odpowiedzialności za naruszenie dyscypliny finansów publicznych ${ }^{2}$, zwana dalej ustawą. Ma ona na celu eliminację niepożądanych wzorców zachowań poprzez możliwość orzeczenia sankcji wobec sprawcy czynu, jak również realizację funkcji prewencyjnej, wpływającej na podnoszenie poziomu staranności dokładanej przy gospodarowaniu środ-

1 M. Zioło, M., Ustawa o odpowiedzialności za naruszenie dyscypliny finansów publicznych jako akt prawny wspomagający zarzq̨dzanie płynnościq finansowq i ryzykiem niewypłacalności jednostek samorządu terytorialnego, [w:] A. Talik, W. Robaczyński A. Babczuk (red.), Dyscyplina finansów publicznych. Podstawy i zakres odpowiedzialności, Warszawa 2015, s. 17.

$2 \quad$ Tekst jedn. Dz.U. z 2013 r. poz. 168. 
kami publicznymi ${ }^{3}$. 0 tym, czy cele te są możliwe do zrealizowania, decydują przede wszystkim rozwiązania zawarte w ustawie. Celem niniejszego opracowania jest wskazanie potrzeby poszerzonej debaty, zarówno na płaszczyźnie teoretycznej, jak i praktycznej, w zakresie skuteczności obowiązujących przepisów ustawy na przykładzie wybranych aspektów czasu popełnienia naruszenia dyscypliny finansów publicznych.

\section{Uregulowania ustawowe w zakresie czasu popełnienie naruszenia dyscypliny finansów publicznych}

Naruszenie dyscypliny finansów publicznych uważa się za popełnione w czasie, w którym sprawca działał lub zaniechał działania, do którego był obowiązany. Za czas, w którym sprawca zaniechał działania, uważa się dzień następujący po upływie terminu, w którym określone działanie powinno nastąpić (art. 21 ustawy).

Ustalenie czasu popełnienia naruszenia jest niezmiernie ważną czynnością dla możliwości skutecznego prowadzenia postępowania w sprawie o naruszenie dyscypliny finansów publicznych. Jest on obligatoryjnym elementem postanowienia o wszczęciu postępowania wyjaśniającego, wniosku o ukaranie, jak też orzeczenia właściwej komisji orzekającej. Zgodnie $\mathrm{z}$ obowiązującym stanem prawnym obowiązek ustalenia czasu naruszenia dyscypliny finansów publicznych ciąży na podmiocie składającym zawiadomienie.

Zgodnie z brzmieniem art. 38 ust. 1 ustawy karalność naruszenia dyscypliny finansów publicznych ustaje, jeżeli od czasu jego popełnienia upłynęły 3 lata. Jeżeli jednak w tym okresie wszczęto postępowanie o naruszenie dyscypliny finansów publicznych, karalność ustaje z upływem 2 lat od zakończenia tego okresu.

3 A. Talik, Dyscyplina finansów publicznych - zagadnienia wprowadzające, „Finanse Komunalne" 2015, nr 7-8, s. 18. 
Istota instytucji przedawnienia polega na ustawowej rezygnacji z karania lub wykonania kary w związku z upływem znacznego czasu ${ }^{4}$. Za jego stosowaniem przemawia to, że upływ czasu osłabia możliwości wychowawczego i prewencyjnego oddziaływania kary; ponadto wraz z upływem czasu utrudnione jest ustalenie wszystkich okoliczności naruszenia, w konsekwencji może nawet dojść do błędów w przypisaniu odpowiedzialności ${ }^{5}$.

Dodać należy, że kwestia ewentualnego przedawnienia karalności naruszenia dyscypliny finansów publicznych jest na tyle istotna, że uniemożliwia prowadzenie postępowania $\mathrm{w}$ tym zakresie - zgodnie bowiem z brzmieniem art. 78 ust. 1 pkt 3) ustawy w przypadku jego zaistnienia nie wszczyna się postępowania, a wszczęte na mocy art. 78 ust. 2 umarza. Co istotne, umorzenie postępowania $\mathrm{z}$ tego względu nie rozstrzyga sprawy merytorycznie, a obwiniony w świetle prawa nie został uznany za winnego popełnienia naruszenia dyscypliny finansów publicznych. Prawomocne postanowienia komisji orzekającej o umorzeniu postępowania $\mathrm{z}$ powodu przedawnienia karalności przekazuje się przewodniczącemu Głównej Komisji Orzekającej, a postanowienia rzecznika dyscypliny o odmowie wszczęcia postępowania wyjaśniającego lub o umorzeniu postępowania wyjaśniającego przekazuje się Głównemu Rzecznikowi Dyscypliny Finansów Publicznych.

\section{Czas popełnienia naruszenia dyscypliny finansów publicznych w doktrynie i orzecznictwie}

Ustawa, zgodnie z założeniami, miała mieć charakter kompleksowy, w związku z czym zrezygnowano z wcześniej funkcjonujących odesłań do innych przepisów, głównie karnych. Brak tych odesłań powo-

4 L. Lipiec-Warzecha, Odpowiedzialność za naruszenie dyscypliny finansów publicznych. Komentarz, Wyd. online http:sip.lex.pl.

5 Tamże. 
duje swoistą trudność interpretatora w przypadku, gdy zawodzi wykładnia gramatyczna ${ }^{6}$. Co prawda brak wyraźnych odesłań nie powoduje niemożności stosowania wykładni systemowej, co możliwe jest jednak pod warunkiem właściwego umieszczenia interpretowanej regulacji. W odniesieniu do systemu odpowiedzialności za naruszenie dyscypliny finansów publicznych brak jest zgody co do charakteru tej odpowiedzialności. W doktrynie przeważają poglądy, iż postępowanie to, chociaż zawiera przepisy o charakterze represyjnym, to jednak nie jest samo w sobie postępowaniem karnym. Również orzecznictwo Głównej Komisji Orzekającej oraz sądów administracyjnych nie jest spójne w tym zakresie - wskazuje się, że postępowanie to ma charakter: administracyjny, karny, dyscyplinarny czy też quasidyscyplinarny ${ }^{7}$.

Dla wskazania, jak różnie interpretowane bywają zagadnienia związane z czasem popełnienia naruszenia dyscypliny finansów publicznych, przywołane zostaną dość obszerne fragmenty trzech orzeczeń Głównej Komisji Orzekającej (GKO).

W często przytaczanym orzeczeniu z dnia 11 lutego 2010 r. GKO wskazała, że: czyn polegający na zaniechaniu jest jednym czynem, niezależnie od czasu trwania zaniechania i stanowi jedno naruszenie dyscypliny finansów publicznych. Czasem popetnienia tego naruszenia jest cały okres trwania zaniechania. (...) Skoro naruszenie polegające na zaniechaniu działania, do którego sprawca jest zobowiązany, trwa przez dłuższy okres czasu, uzasadnione jest liczenie okresu przedawnienia karalności naruszenia od chwili ustania czynu (zaniechania), od

$6 \quad$ M. Smaga, Ustawa o odpowiedzialności za naruszenie dyscypliny finansów publicznych jako ustawa kompleksowa, [w:] M. Smaga, M. Winiarz (red.), Dyscyplina finansów publicznych. Narzędzie prawidłowej gospodarki sektora publicznego, Kraków 2013, s. 283.

7 Więcej - tamże s. 277-286 oraz W. Robaczyński Odpowiedzialność za naruszenie dyscypliny finansów publicznych - wybrane zagadnienia systemowe, [w:] M. Smaga, M. Winiarz (red.), Dyscyplina finansów publicznych. Doktryna, orzecznictwo, praktyka, Warszawa 2015, s. 426-430. 
ostatniego dnia, w którym sprawca pozostawał bierny i nie wywiqzywał się z nałożonego na niego obowiq̨zkü.

W literaturze przedmiotu znaleźć można podobne opinie odnoszące się do czasu popełnienia naruszenia: Przy określaniu czasu popełnienia nie ma obowiq̨zku wskazywania jednej, konkretnej daty naruszenia dyscypliny finansów publicznych. Czasem popełnienia naruszenia dyscypliny finansów publicznych nie musi być data dzienna. $O$ zachowaniach sprawczych z zaniechania można mówić w określonych, ustalonych odcinkach czasowych ${ }^{9}$.

W innym z orzeczeń, wydanym dnia 19 października 2009 r., GKO wskazała natomiast: Podstawowym problemem niniejszej sprawy jest ustalenie czasu popełnienia czynu polegajq̨ego na „nieopłaceniu składki” i czynu polegającego na „opłaceniu składki z przekroczeniem terminu zapłaty". Możliwe sq różne teoretyczne ujęcia tego problemu. Podstawowq okolicznościq wpływającq na rozumienie rozpatrywanych przepisów jest fakt, iż $w$ swej istocie (choć nie w literalnym brzmieniu) czyny te polegają na wywołaniu i utrzymywaniu się przez dłuższy czas stanu bezprawnego. Najbliżej intencji ustawodawcy zdaje się być występująca w prawie karnym teoria tzw. „czynu ciagłego”, tj. czynu, który będąc jednym zachowaniem nie jest jednakże popełniany w jednej chwili lecz trwa przez dłuższy czas. Szczególne zastosowanie ma ta teoria w odniesieniu do czynów polegajacych na zaniechaniu... za czas popełnienia przestępstw rozciagniętych $w$ czasie, wieloczynowych, trwałych, a także o charakterze ciagłym, traktować należy ostatni moment działania sprawcy. Zdaniem GKO konstrukcja czynu ciagłego, choć najlepiej oddająca intencję ustawodawcy nie może zostać przyjęta $w$ systemie odpowiedzialności za naruszenie dyscypliny finansów publicznych. Brak jest bowiem odniesienia umożliwiającego odpowiednie stosowanie przepisów karnych, zaś w ustawie o odpowiedzialności za naruszenie dyscypliny finansów publicznych brak jest przepisu analogicznego do

BDF1/4900/2/2/10/34, http:sip.lex.pl.

T. Bojkowski, Zaniechanie $w$ dyscyplinie finansów publicznych, „Zeszyty Naukowe Uniwersytetu Szczecińskiego" 2011, nr 48, s. 38. 
art. 12 Kodeksu karnego... Druga możliwa interpretacja wynika z przyjętych w prawie cywilnym zasad rzq̨dzących czasem wykonalności zobowiqzań. Jeżeli ustawa nakazuje wykonanie obowiqzku do dnia 15 danego miesiq̨ca, to obowiązek taki został naruszony $w$ dniu 16 tegoż miesiq̨ca. W tym dniu nie jest bowiem możliwe już zachowanie czyniq̨ce zadość przepisom prawa (...) W tej sytuacji dochodzi do zderzenia wykładni celowościowej („czyn jest zaniechaniem, zaś jego ratio legis jest ochrona przed stanem nieregulowania zobowiq̨zań za składki") z wykładnia gramatyczna („penalizowane jest jedynie zaniechanie dokonane w pierwszym dniu terminu przypadającego po dniu zapłaty pozostałe dni sq poza zakresem ustawy"). Zdaniem GKO w sytuacji sprzeczności poszczególnych metod wykładni pierwszeństwo znajduje zawsze wykładnia gramatyczna ${ }^{10}$.

W orzeczeniu z dnia 17 lutego 2011 r. GKO stwierdziła zaś, że: Fakt, że czyn określony $w$ art. 16 ust. 1 u.o.n.d.f.p. staje się naruszeniem dyscypliny finansów publicznych dopiero, jeśli w wyniku niewykonania zobowiq̨zania dojdzie do zapłaty odsetek za opóźnienie, nie ma wpływu na sposób liczenia biegu przedawnienia karalności. Termin przedawnienia karalności także $w$ tym przypadku liczyć należy od pierwszego dnia po ustaniu czynu, zgodnie $z$ reguła określonq $w$ art. 38 ust. 1 u.o.n.d.f.p., a nie od momentu wystapienia jego skutku. Gdyby ustawodawca chciał, by $w$ przypadku naruszenia "skutkowego" termin przedawnienia karalności rozpoczynał bieg od momentu wystapienia skutku popetnionego czynu, ustanowiłby wyjątek od zasady określonej $w$ art. 38 ust. 1 u.o.n.d.f.p., tak jak uczynit to $w$ odniesieniu do przestępstw skutkowych $w$ kodeksie karnym (...). Prawdq jest, że prowadzi to do przedawnienia karalności naruszenia dyscypliny finansów publicznych z art. 16 ust. 1 u.o.n.d.f.p. i uniknięcia odpowiedzialności, jeśli przedłuży się termin zapłaty odsetek o co najmniej 3 lata po zapłacie należności, oraz że rozwiązanie takie może budzić wątpliwości, co do jego słuszności, jednak wprowadzanie nowych, nie znanych ustawie, terminów przedawnienia karalności naruszeń dyscypliny finansów pu-

10 BDF1/4900/51-RN-8/09/1822, http:sip.lex.pl. 
blicznych przez organy pełniq̨ce funkcję oskarżyciela i organy orzekające nie jest dopuszczalne. Organy te maja stosować prawo, a nie je tworzyć11.

Przywołane fragmenty orzeczeń wskazują, jak różnie w praktyce orzeczniczej postrzegane są omawiane zagadnienia. Autor, nie będąc prawnikiem, nie zamierza dokonywać szczegółowej analizy wskazanych orzeczeń, niemniej za niedopuszczalne uznaje tak duże rozbieżności w tak kluczowej sprawie, jak ustalenie charakteru omawianej odpowiedzialności, a co za tym idzie również właściwej wykładni prawa. Powoduje to, że dość podobne w swej istocie stany faktyczne kończą się zasadniczo różnymi rozstrzygnięciami. Mając na uwadze cele przyświecające polskiemu systemowi dochodzenia odpowiedzialności za naruszenie dyscypliny finansów publicznych ${ }^{12}$, należy stwierdzić, że osoby winne zaniechaniom nie powinny unikać odpowiedzialności tylko ze względu na budzące wątpliwości zapisy ustawowe. Wątpliwości te rozwiać powinno wprowadzenie do ustawy konstrukcji czynu ciągłego. Kluczową sprawą jest jednak sprecyzowanie, jakiego rodzaju odpowiedzialnością jest odpowiedzialność za naruszenie dyscypliny finansów publicznych.

\section{Czas popełnienia naruszenia dyscypliny finansów publicznych na przykładzie kontroli Zakładu Ubezpieczeń Społecznych}

Wskazane powyżej przykłady dotyczą dość prostych stanów faktycznych. Udowadniają jednak, że nawet w odniesieniu do nich system dochodzenia odpowiedzialności za naruszenie dyscypliny finansów publicznych bywa zawodny. Kwestia ustalenia czasu popełnienia czynu może być jednak zdecydowanie bardziej skomplikowana.

\footnotetext{
BDF1/4900/113/124-125/RN-27-28/10/3259, http:sip.lex.pl.

Rozważania nad uznaniem odpowiedzialności za naruszenie dyscypliny finansów publicznych za system - zob. W. Robaczyński, Odpowiedzialność za naruszenie dyscypliny finansów publicznych - wybrane zagadnienia systemowe..., s. 426-430.
} 
W art. 14 ustawy określono, że naruszeniem dyscypliny finansów publicznych jest nieopłacenie $\mathrm{w}$ terminie przez jednostkę sektora finansów publicznych składek na ubezpieczenia społeczne, ubezpieczenie zdrowotne, Fundusz Pracy, Fundusz Gwarantowanych Świadczeń Pracowniczych oraz wpłat na Państwowy Fundusz Rehabilitacji Osób Niepełnosprawnych albo ich opłacenie w kwocie niższej niż wynikająca z prawidłowego obliczenia.

Zgodnie z brzmieniem art. 47 ust. 1 pkt 3) ustawy z dnia 13 października 1998 r. o systemie ubezpieczeń społecznych ${ }^{13}$ płatnik składek przesyła deklarację rozliczeniową, imienne raporty miesięczne oraz opłaca składki za dany miesiąc do 15 dnia następnego miesiąca, jeżeli jest „pozostałym płatnikiem”.

Sytuacja ulega znacznemu skomplikowaniu w przypadku, gdy płatnik nie dopełnił obowiązku prawidłowego obliczenia składek i tym samym dopuścił do ich nieuregulowania. $\mathrm{W}$ takim przypadku kwestia ustalenia czasu popełnienia czynu wymaga przeanalizowania kolejnych norm prawa. Zgodnie bowiem z art. 41 ust. 7a wskazanej ustawy o systemie ubezpieczeń społecznych płatnik składek jest zobowiązany złożyć imienny raport miesięczny korygujący w terminie 7 dni od stwierdzenia nieprawidłowości we własnym zakresie lub otrzymania zawiadomienia o stwierdzeniu nieprawidłowości przez ZUS, z zastrzeżeniem ust. 7b. We wskazanym ustępie wskazano, że jeżeli konieczność korekty danych podanych $\mathrm{w}$ imiennym raporcie miesięcznym jest wynikiem stwierdzenia nieprawidłowości przez ZUS w drodze:

1. decyzji - imienny raport miesięczny korygujący powinien być złożony nie później niż w terminie 7 dni od uprawomocnienia się decyzji,

2. kontroli - imienny raport miesięczny korygujący powinien być złożony nie później niż w terminie 30 dni od dnia otrzymania protokołu kontroli.

13 Tekst jedn. Dz.U. z 2015 r. poz. 121 ze zm. 
W przypadku, gdy to ZUS w wyniku przeprowadzonej kontroli stwierdzi, że płatnik nie dopełnił obowiązku prawidłowego obliczenia składek i dopuścił do ich nieuregulowania, a płatnik składek nie złoży raportów korygujących i nie opłaci składek, to właśnie ZUS zobligowany jest do wydania stosownych decyzji. Od decyzji tych służy odwołanie, a zdarza się, że cała droga odwoławcza trwa ponad trzy lata.

W tak skomplikowanym stanie prawnym zarówno strony postępowania, jak też organ zawiadamiający w bardzo różny sposób interpretują czas popełnienia naruszenia dyscypliny finansów publicznych; również w odniesieniu do składów orzekających nie można mieć pewności, że w jednakowy sposób ustalą one ten czas. Co również prawdopodobne - znaczna część sprawców tego typu przewinień nigdy nie zostanie ukarana, gdyż postępowania w tym zakresie mogą zostać umorzone ze względu na przedawnienie ich karalności. Niewątpliwie zamierzeniem ustawodawcy nie było dopuszczenie do sytuacji, w której znamiona czynu zabronionego pojawiają się, gdy jego karalność ustała już z powodu przedawnienia. Zastosowanie konstrukcji czynu ciągłego pozwoliłoby uniknąć znacznej części tego typu przypadków.

\section{Wnioski}

Obowiązujący system odpowiedzialności dyscypliny finansów publicznych nie jest z pewnością systemem doskonałym, czego dowodem jest chociażby zasadniczo różne orzecznictwo w bardzo podobnych stanach faktycznych. Ponadto pamiętać należy o zmieniającym się otoczeniu jednostek sektora finansów publicznych, co system też powinien uwzględniać ${ }^{14}$. To wszystko powoduje, że zmiany ustawy o odpowiedzialności za naruszenie dyscypliny finansów publicznych

14 Przykłady - zob. M. Dylewski, Adekwatność rozwiq̨zań w zakresie dyscypliny finansów publicznych a nowe trendy $w$ gospodarce finansowej, [w:] M. Smaga, M. Winiarz (red.), Dyscyplina finansów publicznych..., s. 144-166. 
wydają się być nieuniknione ${ }^{15}$. Niniejszy tekst stanowi zaledwie wstęp do opracowania szczegółowych rozwiązań w tym zakresie. Mając na względzie cele, jakie przyświecały stworzeniu systemu, w pełni uzasadnione wydaje się wprowadzenie do niego konstrukcji czynu ciągłego. Powinno to pozytywnie wpłynąć na prewencyjną rolę ustawy, a w opinii autora jest to zdecydowanie najważniejszy jej cel.

Postulowana w niniejszym opracowaniu zmiana wydaje się nie budzić zasadniczych wątpliwości. Ustawodawca będzie się jednak musiał zastanowić nad kwestiami znacznie trudniejszymi. Nie da się bowiem uciec od coraz częściej postulowanych zmian mających na celu bardziej efektywne gospodarowanie środkami publicznymi. Opracowanie skutecznych uregulowań w tym zakresie z całą pewnością nie będzie zadaniem łatwym.

\section{Literatura:}

Bojkowski T., Zaniechanie $w$ dyscyplinie finansów publicznych, „Zeszyty Naukowe Uniwersytetu Szczecińskiego" 2011, nr 48.

Dylewski M., Adekwatność rozwiązań w zakresie dyscypliny finansów publicznych a nowe trendy w gospodarce finansowej, [w:] M. Smaga, M. Winiarz (red.), Dyscyplina finansów publicznych. Doktryna, orzecznictwo, praktyka, Wydawnictwo C.H. Beck, Warszawa 2015.

JST do kontroli. Prezes NIK: nadmierny jest zakres zadań i kompetencji RIO, http://samorzad.pap.pl, (dostęp: 12.04.2016 r.).

Lipiec-Warzecha L., Odpowiedzialność za naruszenie dyscypliny finansów publicznych. Komentarz, wyd. online, http:sip.lex.pl.

Robaczyński W., Odpowiedzialność za naruszenie dyscypliny finansów publicznych - wybrane zagadnienia systemowe, [w:] M. Smaga, M. Winiarz (red.), Dyscyplina finansów publicznych. Doktryna, orzecznictwo, praktyka, Wydawnictwo C.H. Beck, Warszawa 2015.

Smaga M., Ustawa o odpowiedzialności za naruszenie dyscypliny finansów publicznych jako ustawa kompleksowa, [w:] M. Smaga, M. Winiarz (red.),

150 zmiany te postulują również przedstawiciele organów kontrolnych - zob. JST do kontroli. Prezes NIK: nadmierny jest zakres zadań $i$ kompetencji RIO, http://samorzad.pap.pl (dostęp: 12.04.2016 r.). 
Dyscyplina finansów publicznych. Narzędzie prawidłowej gospodarki sektora publicznego, Wydawnictwo Publicus, Kraków 2013.

Szostak R., O potrzebie usprawnienia odpowiedzialności za niektóre uchybienia popełniane przy udzielaniu lub wykonywaniu zamówień publicznych, [w:] M. Smaga, M. Winiarz (red.), Dyscyplina finansów publicznych. Doktryna, orzecznictwo, praktyka, Wydawnictwo C.H. Beck, Warszawa 2015.

Talik A., Dyscyplina finansów publicznych - zagadnienia wprowadzające, „Finanse Komunalne" 2015, nr 7-8, s. 18-29.

Zioło M., Ustawa o odpowiedzialności za naruszenie dyscypliny finansów publicznych jako akt prawny wspomagający zarzq̨dzanie płynnościq finansowa i ryzykiem niewypłacalności jednostek samorzq̨du terytorialnego, [w:] A. Talik, W. Robaczyński, A. Babczuk, Dyscyplina finansów publicznych. Podstawy i zakres odpowiedzialności, Wydawnictwo C.H. Beck, Warszawa 2015. 